\title{
Animating 'refugeeness' through vulnerabilities: worthiness of long-term exile in resettlement claims among Somali refugees in Kenya
}

\author{
Fred Nyongesa Ikanda
}

\begin{abstract}
Introduction
Moha ${ }^{1}$ has just arrived at the police station from Dadaab, where he had gone to attend his resettlement interview. A crowd of people is forming, anxious to hear about it. There are five police officers, six Somali ${ }^{2}$ refugees (four men and two women), Osman (who identified himself as a local), and two non-Somali Kenyans who work at the police canteen. 'How did it go?' I ask what everyone is apparently eager to know. 'It went well,' he answers me with a huge grin. He is a popular figure at the police canteen, where he spends almost his entire life arriving there as early as 9 a.m. and staying until after midnight before retiring to the camp. All the while, he would be chewing miraa (a shrub chewed as a mild stimulant, also called khat), interspersed with a bottle of beer. He is clearly savouring the moment as he starts to narrate the interview details:
\end{abstract}

They expected me to recount stories of atrocities as many of my colleagues do when they get the chance. Instead, I thanked them and told them I was looking forward to their kind consideration. One mzung $u$ [white person] asked me to narrate my problems and I told her: 'I am a refugee just like those in other Kenyan camps. The problems that refugees go through are the same ones I also encounter and I know you have heard many stories in that regard so I might tire you if I repeat them. What we have in common is that we are all called refugees so we face the same problems as our label suggests.' They all burst out in laughter and told me they will communicate their decision.

Osman seems annoyed that Moha behaved so 'casually' considering the rarity and importance of resettlement interviews, but Moha is unapologetic:

I knew they were expecting me to exaggerate my problems. They hear many things from people. You can only succeed with saying problems if they are already known. I have not reported anything to the police, Lutheran World Federation or $\mathrm{CARE}^{3}$ about facing discrimination and they would have used that as an excuse to fail me. But I defended myself and said I am an old refugee, with over twenty years' experience.

Fred Nyongesa Ikanda is a lecturer in the Department of Sociology and Anthropology, Maseno University, Kenya. Email: fikanda@gmail.com

${ }^{1}$ I have used pseudonyms instead of people's actual names to protect the identity of my informants.

${ }^{2}$ The local residents in the study area belong to the Somali ethnic group. Since most refugees from Somalia also belong to the same ethnic group, I use the word 'locals' to refer to Kenyan nationals and refer to refugees from Somalia as 'Somali refugees'.

${ }^{3}$ CARE International provides various social services, including the safeguarding of gender and minority rights, while the Lutheran World Federation is in charge of camp administration. 
This vignette was recorded in my field notes about halfway through my twelve months of ethnographic fieldwork (from August 2011 to August 2012) in a village that lies adjacent to Dagahaley camp, where Somali refugees have been living since 1992. The village is part of the Dadaab complex (a group of camps located close together, including Dagahaley, Hagadera, Ifo, Ifo 2 and Kambioos, which are typically regarded as one) in Garissa County, northeastern Kenya. The vignette illuminates the limbo-like state that refugees inhabit in the area. ${ }^{4}$ It shows not only that successful resettlement claims pivoted on vulnerabilities that might garner the attention and support of humanitarian actors, but also that long-term camp residents perceived that those making such claims were worthy of being considered for resettlement. Resettlement is the 'selection and transfer of refugees from a State in which they have sought protection to a third State which has agreed to admit them - as refugees - with permanent refugee status' (UNHCR 2011: 3). Although the office of the United Nations High Commissioner for Refugees (UNHCR) recommends resettlement as a last resort to solving the refugee problem, it has become the most attractive option for Somali refugees in Kenya. Most are unable to utilize local integration or voluntary repatriation - the preferred and most durable solutions - due to the declining asylum conditions in Kenya and the relentless Somali conflict. It is because so-called durable solutions have become increasingly elusive that Somalis, like many other African refugees, are living in a protracted refugee situation. ${ }^{5}$ Thus, humanitarianism - which covers efforts that generally seek to alleviate human suffering during crises - has increasingly been transformed from a temporary measure to a long-term concern.

Resettlement, however, despite appearing as the only remaining option, was itself elusive. Informal discussions were dominated by its putative benefits, including remittances and other diasporic imaginings. But because it was rarely achieved, few people ever realized their diasporic dreams. In 2014, for example, the local UNHCR office submitted 6,800 refugees for resettlement, which represented only 1 per cent of Kenya's entire refugee population (UNHCR 2015: 15). One consequence of the relentlessness of exile, as implied in the vignette above, is that it ignited debates inside the camps about which long-term residents might be worthy of resettlement. This discourse was particularly entrenched at the beginning of 2006 when the UNHCR started to consider such residents for resettlement. Prior to that period, a series of other categories of vulnerability had succeeded each other as deserving to be prioritized for resettlement. As many of my informants recounted, rape as a form of vulnerability dominated resettlement schemes in the mid-1990s before being displaced by minority vulnerability, which was largely privileged between the late 1990s and the mid-2000s. The

\footnotetext{
${ }^{4}$ The Kenyan government has long called for the closure of the Dadaab camps, citing security concerns. Consequently, UNHCR recently announced that it was working with the government to voluntarily repatriate refugees back to Somalia, but few refugees so far have shown a willingness to abide by this resolution.

${ }^{5}$ Refugees can be regarded as being in a protracted situation if they have lived in host countries for more than five years and there is still no solution in sight by means of voluntary repatriation, local integration or resettlement. Approximately 3 million African refugees found themselves in protracted situations by 2002, including refugees from Angola, Burundi, Eritrea, Liberia, Sahrawi, Sierra Leone, Somalia and Sudan (see Crisp 2005).
} 
difficulty of navigating the narrow resettlement path, therefore, was exacerbated by the privileging of ever-moving vulnerability categories, which forced people such as Moha to constantly adapt their narratives of self-identification to humanitarian technologies of governance.

Because long-term camp residents were the least likely to return to Somalia, the Kenyan government was concerned that they were becoming permanently rooted in exile, and made moves to consider resettlement as a viable option. As I show throughout the article, however, it was not just long-term residence in the camp that counted. This long-term camp stay had to be accompanied by a kind of helplessness, often personified by a resident's inability to have connections outside the camps. This requirement, as I show below, posed a considerable dilemma for refugees because it implicitly pegged the actualization of the resettlement dream on severing the relationships and activities that had kept the camps going for so long. In the Dadaab setting, locals and refugees belong to the same ethnic group, and they have had a history of cross-border interactions long before the advent of the camps, which made it almost impossible not to have contacts outside the camps.

Given this tactic of underplaying local connections, my own research experience left me wondering about the politics of revealing these: of identifying 'locals' and 'refugees' with overlapping relationships and experiences. My host's father, for instance, had previously stayed in the camp as a registered 'refugee' from 1992 to 2007 , when he relocated to the village inhabited by 'locals' to become its chairman. ${ }^{6}$ Like many other villagers, he had one family (wife and children) in the camp and another one in the village. This sort of fluidity prompted me to abandon my initial research objective of focusing on the ways in which locals coped with the protracted refugee situation: it did not make sense to study 'locals' in isolation from 'refugees'. It was not uncommon for people to mask the connections that made their lives less certain while improvising on kinship to flexibly inhabit both 'local' and 'refugee' identities in their contextual claim making.

What we see at Dadaab is not the image of the UNHCR bureaucracy as an abstract, monolithic entity whose operation is governed by standard procedures, as some authors contend (see, for example, Harrell-Bond 1986; Hyndman 1996), but a body that is strategic: it adjusts to the actions of refugees to maintain the status quo by keeping the need for humanitarianism alive. This interactive process produced two subject positions that were diametrically opposed: refugees who constantly strived to raise their vulnerability profile in accordance with what was being prioritized in resettlement schemes; and humanitarian actors who sought to fix and define the situation by discouraging the dynamism that connections brought to the camps.

In this article, I highlight the subjective, social and political contradictions that were set in motion when the humanitarian temporality of crisis became a near permanent condition. In particular, I discuss 'refugeeness' as a process of becoming in which resettlement pivoted on being a disconnected long-term camp resident and/or a bearer of peculiar vulnerabilities. I argue that, although Somali refugees did not always self-identify as vulnerable, the resettlement eligibility criteria

\footnotetext{
${ }^{6}$ The area's chief informed me that he had founded the village in the late 1990s.
} 
prompted them to keep vulnerabilities alive. The process of enlivening their sense of helplessness generated uncertainties and suspicion within social relations.

Humanitarianism commonly invokes particular categories of vulnerability to activate fundraising procedures (Pandolfi 2008), and refugees have to convincingly display these vulnerabilities to be accepted as genuine subjects of compassion (Branch 2009; Malkki 1995; Ticktin 2006; Sandvik 2011). Drawing on Giorgio Agamben's 'bare life' appraisal of humanitarianism, Miriam Ticktin demonstrates how humanitarian practices produce negative outcomes in the name of ameliorating suffering. She shows how the humanitarian system hinges its assistance on exceptionality: recipients must exhibit a limited version of humanity, personified by an apolitical, suffering body, in order to be deemed a worthy recipient of humanitarian rewards. Making exceptionality claims, however, increases the suspicion with which officials assess refugees, which leads to massive exclusions often through arbitrary rules that are unknown to those in need of asylum (Ticktin 2006). It is a contradiction that although the UNHCR demands transparency from refugees, its own actions are characterized by opacity, arbitrary measures, and power inequalities between its staff and the refugee clients it exists to serve (Harrell-Bond 2002; Sandvik 2011; Thomson 2012). Following these authors, I argue that suspicion played an important role in enacting resettlement practices that sought to limit the number of those eligible. To begin with, it was difficult to settle for a lengthy period of time without establishing contacts outside the camps, but many long-term residents were disqualified from the resettlement process for having relatives with Kenyan identity cards (IDs). Similarly, the official designation of a minority group as being under unusual threat increased the suspicion with which resettlement officials perceived claims to belong to that very group. Refugeeness was, therefore, a labour-intensive process that demanded sacrifice and new ideas, but the system viewed such strategizing individuals with suspicion. My aim, however, is to shift the emphasis away from 'bare life' conceptions and to suggest instead that bureaucracies do not always have the last word. Refugees were unwavering in following paths that were meaningful to them, rather than blindly following humanitarian policies that were disconnected from reality. As I discuss below, and as the opening vignette suggests, the ultimate aim of many Somali refugees was to positively transform their lives, or to continue striving for onward migration in their ceaseless search for paradise-like destinations (Abdi 2015), unlike in other contexts (see, for example, Ticktin 2006) where immigrants sought vulnerabilities that irreversibly rendered them desirable subjects of humanitarianism.

Questions of uncertainty are key to my study (see, for example, Calkins 2016; Haram 2004; Vigh 2009). As in other contexts where vulnerable people persistently seek to produce continuity in their lives by actively responding to their dire situation (Boholm 2003; Jenkins et al. 2005), Somalis actively try to improve their circumstances: they are neither mere victims lacking agency nor are they 'fully free actors' with limitless agency (Utas 2005: 426). But, while uncertainty can prompt people to imagine alternative possibilities and outcomes, it can also create doubt and thereby limit their capacity to act (Calkins 2016). Following Henrik Vigh (2009), who deploys the concept of social navigation as a metaphor to illustrate how people in prolonged situations of crisis comprehend and manage their social environment, I suggest that the strategies that refugees deploy to gain humanitarian benefits in Kenyan camps may be perceived as responses to 
uncertainty: to the constantly emergent ways of prioritizing vulnerability. This differs from another Kenyan context, where 'organizing resettlement' is viewed purely as a manipulative process (Jansen 2008: 575). The dilemma for many refugees, therefore, was not just the idea that the best way to leave the camps through resettlement was to stay there ever longer, but also the possibility that, in the future, they could be called upon to abandon or render invisible the refugeeness they had accumulated precisely through this long period of settlement. Accordingly, their strategies were situated within the context of the uncertainties that were produced and sustained by subjective humanitarian practices.

I begin by outlining the study context. I then show how refugee uncertainty was fuelled by the UNHCR's selection criteria, which were incompatible with refugees' lived realities. This is followed by a consideration of the ways in which refugee uncertainties were exacerbated by different actors' perceptions about vulnerability. Finally, I discuss refugeeness as a process of becoming in relation to the emergence of long-term camp presence as a prized form of vulnerability.

\section{Study setting}

The Dadaab camps were initially designed to host 90,000 refugees following the outbreak of war in Somalia in 1991. During my fieldwork, however, they were home to over 450,000 refugees - mostly Somalis who were escaping the war and the catastrophic drought in the Horn of Africa at the time. Somali locals and refugees originate from a patrilineal, Islamic, nomadic pastoralist group divided into clans, sub-clans and lineages. Also present in the Dadaab camps, however, were a considerable number of Somali Bantu: members of a minority Islamic group who reside in southern Somalia but speak a different language. They are descendants of several Bantu ethnic groups that were formerly sold into slavery in Africa (see Besteman 1999). The political border between Kenya and Somalia has historically been irrelevant to Somali nomads on either side of it (CASA Consulting 2001; Lyons 1994). The fluidity between local and refugee was cemented by the fact that the camps are situated only about 75 kilometres from the common border, which often created unstable notions of 'locals' and 'refugees'.

That said, Somali sociality is replete with clan rivalries that have, indeed, been blamed for igniting the civil war (see, for example, CASA Consulting 2001). Similarly, refugee flight patterns were initially shaped by kinship: the majority of those who arrived with the 1991-92 refugee wave belonged to the Ogaden sub-clan, whose kinsmen traditionally inhabit the camp area (CASA Consulting 2001; Goldsmith 1997). Moreover, camp configurations were generally shaped by kinship. Minorities such as Somali Bantus were housed in specific areas for their own safety, and other Somalis preferred to settle in blocks inhabited by their close relatives, sometimes through buying land in those areas. However, the refugee wave of 2011-12 - and to some extent the influx in 2006-08 that was occasioned by the war that brought Al-Shabaab into power - was distinctive because kinship considerations played a lesser role (Ikanda 2014). Earlier arrivals (who defined themselves as 'old' refugees) referred to these later groups as 'new refugees'. 
I conducted participant observation using a mixture of Somali and Swahili languages because I had only basic knowledge of the Somali language from a previous research project at Dadaab. I therefore enlisted the services of a Somali language teacher who also acted as my guide in the initial stages of my fieldwork. My participant observation revolved around three contexts: in the village where I stayed, at the police canteen where I usually took drinks, and inside the camp where I often visited my close informants. I had established close contact with around ten families inside the camp whom I visited almost daily with my language teacher. I would then return to the village in the evenings and typically spend my time with a group of men who often chewed miraa in my host father's compound.

\section{The inaptness of the UNHCR's resettlement procedures}

Humanitarianism propagated policies that did not reflect the realities on the ground. Thus, for instance, the person most likely to be resettled was one who successfully masked the activities that did not conform to social understandings of plausible refugeeness. Refugeeness as a process of becoming was productive for locals and refugees, considering the local/refugee fluidity that largely rendered illogical the humanitarian practice of delineating refugees as an 'extreme compassion' category.

Unrealistic policies such as linking resettlement to being a long-term, unconnected camp resident generated considerable uncertainty. According to the UNHCR's Resettlement Handbook, resettlement is an indispensable aspect of refugee administration for various reasons. It helps to reunite refugee families that are divided by flight from persecution and displacement; it may be the only way of ending the refugee situation in many hosting contexts; and it might be the single option for safeguarding refugees facing forceful refoulement (return to the country of origin) or those whose physical safety is seriously threatened (UNHCR 2011: 4). In carrying out this core mandate, the UNHCR works in partnership with states that offer permanent residence to refugees. Although the number of resettlement states had grown from the ten 'traditional' countries in the 1980 s to twenty-five countries by 2011 , the available places have failed to keep pace with the number of refugees in need of resettlement (ibid.: 65-6).

The UNHCR outlines three priority levels for determining when resettlement is the appropriate solution: emergency (where imminence of security and/or a medical condition necessitates removal from the threatening conditions), urgent (catering for refugees with serious medical risks or other vulnerabilities requiring expedited resettlement within six weeks of submission), and normal (where there are no immediate medical, social or security concerns that would merit expedited processing) (UNHCR 2011: 246). These priority levels are further broken down into several criteria, which clearly create more 'qualified' people than there are slots for them. These levels include legal and physical protection needs, survivors of violence and torture, medical needs, women and girls at risk, family reunification, and children and adolescents ( ibid.). The UNHCR policy guidelines mapped imperfectly onto the way people managed their lives at Dagahaley. To begin with, shared 'Somaliness' often rendered problematic the refugee/local categories that 
senior bureaucratic officials (mostly non-Somalis) sought to impose. This fluidity was further complicated by nomadic pastoralism, which had problematized the idea of 'home' since many families had members distributed across the camp, in local villages, and among the herders in Kenya and Somalia. As Herz (2008) has noted, many Somalis seem to operate on the principle of strategically positioning relatives in different spaces to simultaneously exploit the potential offered by multiple places, including resettlement in Western countries. Because one could access resources only by adhering to bureaucratic categorizations, many people contextually occupied particular identities but otherwise maintained their previous kin-based relations. This often blurred the refugee/local distinction still further. Thus, for instance, it was not uncommon for 'locals' to be granted resettlement opportunities, contrary to the precondition that requires principal applicants to be refugees (UNHCR 2011: 9). An example is the case of Sahat - a high-profile local politician who was elected the area's councillor in Kenya's 2002 general election, but resigned in 2006 to take up a resettlement opportunity in the US. During my fieldwork, he returned to establish an NGO to fight for 'locals' rights', even though his family had remained in the US as resettled refugees. Additionally, many villagers and 'old' refugees held both refugee and local documents that they used to gain access to camp and village resources at the same time. Refugee cards entitled locals to free food and sometimes enabled them to apply for resettlement, while Kenyan IDs guaranteed unrestricted travel for refugees who were officially supposed to be confined to the camps (Horst 2006; Hyndman 1996).

More than anything else, perhaps, the 'Principle of Family Unity' differed radically from the lived realities of Somalis. According to the Resettlement Handbook, this principle, which ostensibly forms a core aspect of refugee protection, extends the rights granted to a refugee to members of his or her family. This principle 'derives directly from the universally recognized right to family life' and is 'supported by the principle, set forth in both the Universal Declaration of Human Rights of 1948 and the International Covenant on Civil and Political Rights of 1966' (UNHCR 2011: 176). The UNHCR extensively cites the provision on the unity of the family to support its stated aim of considering the entire family if one of the members succeeds in the resettlement process. In practice, however, the benevolent aspirations espoused by this policy were often overshadowed by the rider that guided its operation: 'if the resettlement State has accepted only part of the family and will not reconsider the split decision, the UNHCR should advise the family to consider withdrawal and resubmission of all linked cases to another country in order that no individual is left behind' (ibid.: 368). On many occasions, the policy's implementation resulted in locking out entire families on discovery that one of the members listed on the ration card was a Kenyan. One of its victims was a friend staying at the UNHCR's safe haven. The UNHCR had housed him following repeated attacks on his family in the camp due to what he described as his minority status. He was then categorized as an urgent case needing resettlement, but shortly after his interview, he was notified that the process had been cancelled because the computer database had revealed that his wife was a holder of a Kenyan ID. His vulnerability evaporated overnight when the UNHCR ordered him to vacate its compound and return to the camp. Returning to the camp, however, was complicated by the fact that he had already sold his plot in readiness for the then impending journey to the US. 
This created a standoff between him and the UNHCR that was still ongoing when I left. In many similar cases, the principle of family unity was implemented in a manner that shut down the chances of resettlement. Cases in which families were barred from being considered for resettlement due to one of their members having a Kenyan ID dominated informal discussions and debates in campbased media, as reflected in the views of Abdi Abdullahi, a youth leader:

Of late, the refugee resettlement programme suffered a major relapse, apparently inflicted by the folly of the refugees acquiring Kenyan IDs ... The most deplorable episode involving this predicament is of a holder of an independent ration card who has been cleared individually but unfortunately has been subjected to a distant relative's fault and whose process has been brought to [a] screeching halt. ${ }^{7}$

The UNHCR's (2011) insistence on the unity of the family is clearly justified, especially in the difficult refugee circumstances in which the family provides psychological and emotional support. Its prescriptions do not, however, fit well with the Somali strategy of scattering family members in multiple places. This practice is not very different from the claims by ethnographers that Somalis are organized around the segmentary lineage logic of uniting and breaking up lineage groups based on the presence or absence of war (see Lewis 1999 [1961]). Thus, the scattering of family members that is depicted in recent literature as a survival strategy in a war setting (see, for example, Lindley 2008) is rooted in earlier Somali practices of forming and breaking groups as a means of governance and access to resources. Recent literature has demonstrated, moreover, that family dispersions preceded the war (Abdi 2015). Certainly, the story of resettlement over the past two decades has been characterized by family separation.

Moha, whose interview experience was quoted at the beginning of the article, is a good example of the diverse Somali connections that are engendered by the dispersal of family members. He was often ambivalent about his decision to remain helplessly stuck in the camp, not least because he received a monthly $\$ 300$ remittance from his family members residing in the US and had previously run business ventures in several Kenyan cities that he abandoned in the expectation of realizing the near impossible dream of being resettled. When war broke out, his father, then a high-ranking government official, used his wealth and former position to take his family to Utange camp on Kenya's coast in 1991. Because of its good economic and weather conditions, they preferred Utange over Dadaab, where the majority of refugees were accommodated. Four years later, following the closure of Utange, they found themselves back in Dadaab again. This turn of events forced Moha's father to seek refuge in Djibouti, where he used his political connections to obtain temporary asylum in Italy and eventual resettlement in Minnesota in the US. Moha's mother and elder brother joined his father in the US after five years, leaving him behind with his younger brother and sister, who later married and moved back to Somalia. Using the monthly $\$ 300$ he received from his father and elder brother, he moved out of Dadaab in 2000 and started an informal oil business in western Kenya that lasted three years. His wife and children had remained in Dadaab. However, they joined him when he relocated to

\footnotetext{
7'Identity crisis', The Refugee Newsletter, September-December 2011.
} 
Nairobi's Eastleigh area, where he ran a bar business for two years before returning to Dadaab in 2005. His decision was largely informed by the feeling that his father was taking too long to help him join the rest of the family in the US, and his resolve to secure resettlement was particularly fuelled by the then ongoing reports of group resettlement of Somali Bantu minorities. He briefly assumed Somali Bantu identity, but when he realized that 'new Somali Bantus' were not being considered, he quickly wrote a letter to the UNHCR instead, stating that his Rahanwiin 'minority' clan was being consistently targeted by stronger clans and that his position as 'youth chairman' of the clan put him in constant danger inside the camp. When this tactic failed, he decided to remain in the camp, which he perceived as offering a more realistic chance of actualizing his long-term dream. Meanwhile, his wife went back to her parents' home in the border town of Wajir in Kenya with their children.

Moha's resettlement interview described above turned out to be a success. The UNHCR duly notified him that they had forwarded his application to the receiving country that would resettle both him and the younger brother with whom he shared a ration card. The good news was, however, short-lived. Four months later he received another letter from the UNHCR informing him that his application was under review because his younger brother's computer data had revealed he was a Kenyan. He initially thought this was a mistake, but the brother confirmed that he had been issued with an ID at a nearby town in 2005 after bribing clan elders in charge of the vetting process. He was in the process of appealing the UNHCR's decision when I was ending my fieldwork, claiming in a letter he wrote to them that it was unfair to be denied his 'right' to be resettled due to his brother's mistake. However, he was aware that it was not going to be easy, considering the many cases of people who had been disqualified on similar grounds.

\section{Unsynchronized vulnerability understandings}

The prioritization of particular categories of people as deserving resettlement set the stage for different imaginings of what constituted vulnerability. In turn, these conceptions structured the responses of different actors to humanitarianism. As the above cases have underlined, senior humanitarian actors did not consider refugees with connections outside the camps as being vulnerable, for example. They also linked Somali practices of situationally inhabiting particular identities to dishonest behaviour. They therefore constantly created arbitrary borders as a way of fixing and defining the situation. This created an endless sense of uncertainty that in turn drove people to inhabit identities that corresponded to privileged vulnerabilities.

When the Refugee Bill was passed by parliament in 2006, for example, the UNHCR and the Kenyan registration systems were synchronized as a way of curbing local/refugee fluidity. Until then, the UNHCR had been registering refugees because Kenya lacked the necessary legal framework. The enactment of the bill became a way of streamlining recipients of refugee rations, resettlement in Western countries and Kenyan IDs. Certainly, during my fieldwork, stories of being 'refused by the computer' had become a habitual way of signalling the 
many cases of people who were denied IDs and resettlement opportunities whenever their claims conflicted with the database information about their identities. In essence, the need to exploit the opportunities offered by belonging to both groups had emerged as a source of social and moral ambivalence, since success in assuming one identity often meant a loss of another. Remarkably, some people continued to buy ration cards from refugees who opted to return home, which underscored the difficulty of totally eliminating local/refugee fluidity.

A separate, and perhaps more radical, interpretation of refugee vulnerability also existed among state officials. My interactions with them often left me with a sense that they did not associate camps with vulnerability. A case in point is a meeting I once had with the District Commissioner (DC) in his office. I had gone there to ask when the government would resume the refugee registration exercise that had then been suspended indefinitely. As he put it:

It is wrong for you to sympathize with those people. They are former warlords who should be facing charges of crimes against humanity, yet they are highly protected here. The picture I have about refugees is that of helpless people. Here, the so-called camps are full of millionaire merchants and murderers who are establishing themselves in every part of this country. That is why we are determined to close these camps.

The DC was addressing me as a fellow Kenyan who should have been on the 'government's side'. Just that morning, a UNHCR team had come to ask him the same question and he had told them what he had told me, he explained. These sentiments mirror the misgivings of many Kenyans about people of Somali ethnicity. Their insecurities, based in part on past insurgency activities, largely account for the marginal position of Kenyan Somalis within the wider Kenyan context (see Lochery 2012; Markakis 1987). A managing editor of a leading Kenyan newspaper once summarized the standard litany of many Kenyans about Somali refugees: 'When they are not coveting parts of our territory, they are accusing us of stealing their resources or massacring us in shopping malls.' ${ }^{8}$ Being on the 'government's side', therefore, seemed to imply support for such demagogic conclusions about Somalis. It appears, then, that the factors that shaped government officials' conceptions of refugees were different from those of humanitarian actors.

The DC's views, however, corresponded to those of humanitarian officials in another camp context who thought that proper refugees should not be well off (Malkki 1995). There was, in fact, a widely held view in the camp areas that Somalis did not resemble proper refugees because they owned most of the wealth at Dadaab. These views gained particular traction because a considerable number of refugees had thriving business enterprises both inside the camp and in the towns that are situated nearby. These views were also fuelled by the fact that the remittances that many refugee families received from their relatives in the diaspora had visibly transformed camp towns into centres of intense business activity (cf. Horst 2006).

If humanitarian practices led to an ever-present sense of uncertainty, the refugees' adjustment to the unfolding social environment was almost as swift. Their social navigation essentially highlighted the many complex ways in which

\footnotetext{
${ }^{8}$ Mutuma Mathiu, Daily Nation, 4 October 2013.
} 
people 'imagine and anticipate the movement and influence of social forces' (Vigh 2009: 420). Indeed, the DC's remarks are testimony to the fact that the power of bureaucratic structures to dictate the agenda was not without its limits or constraints. Somalis continuously improvised to manoeuvre around bureaucratic restrictions and strived constantly to keep pace with preferred vulnerability forms in their struggle to secure resettlement. This struggle was, however, often complicated by the fact that the process of prioritizing forms of vulnerability was always evolving. As mentioned above, rape victims were among the largest beneficiaries of resettlement in the 1990s. In the early 2000s, however, the UNHCR started supplying refugee households with firewood to prevent women from venturing into the bush for this precious commodity and rape lost its privileged status in agency circles (see CASA Consulting 2001). Moha once explained how it had become problematic for rape victims to justify their presence in the bush where most of these incidents had occurred in the past. Similarly, minorities such as Somali Bantu were given priority in the late 1990s, but those who came in the early 2000s said they were denied registration until the then ongoing group resettlement was completed. One such victim had this to say:

When we returned with my brother from sea fishing, my wife had been shot dead but our infant baby was alive and still suckling her, so we fled to Hagadera in 2000. A Somali Bantu man accommodated us for a year as we tried to get ration cards. He then grew tired and asked us to leave so we came to Dagahaley in 2001. We again failed to get ration cards so we joined Somali Bantus. In 2004, I changed my name to Haji because the name Mohamed had brought me nothing but misfortune. I was then issued with a ration card but I later learned that they had been suspecting we came because of being enticed by resettlement stories.

The official designation of Somali Bantus as an ethnic group that was under a certain level of threat, therefore, evidently fuelled the suspicion with which resettlement officers viewed those who claimed to belong to this group. Somali Bantus' vulnerability was being prioritized for resettlement at that time because they had undergone disproportionate suffering as a group. They had largely been sitting ducks in the conflict because of their minority status (Lewis 1998). They had also been discriminated against historically for having hard, 'kinky' hair (Besteman 1999), but, ironically, these physical features evaporated when their turn came to benefit from resettlement: many Somalis, like Moha, quickly assumed the Somali Bantu identity. Agency officials were probably overwhelmed by the many applications that sought to exploit the Somali Bantus' ability to be resettled at that time. Their decision to discourage the influx of new Somali Bantus, however, appears to have shut out genuine cases, as Mohamed's experiences show. ${ }^{9}$ This turn of events, therefore, made many people - minorities included - realize that earlier vulnerability priorities had evolved.

The conversation between Moha and Osman cited at the start of this article illustrates how the awareness of privileged forms of vulnerability is woven into daily narratives, and in turn shapes actors' behaviour. Like many other locals,

\footnotetext{
${ }^{9}$ It is possible that some people might not have been registered because of bureaucratic bottlenecks that often make the process slow (see Horst 2006: 96).
} 
Osman's family had decided to register his seventeen-year-old brother as a refugee in the hope that he would be granted resettlement. Following Moha's interview, Osman explained that his brother's resettlement case was being fast-tracked because he had been registered as a minor who had lost his entire family to the war. Osman himself had narrowly missed out when his plan to marry a woman whose family was about to be resettled backfired. He was 'discovered' to be a Kenyan and his wife was left behind when her family went to the US. This had reinforced Osman's resolve to bar his younger brother from applying for a Kenyan ID.

Moha and Osman's conversation also shows how the prioritization of 'normal' cases often translated into considering 'old' refugees who were deemed to have stayed longest in exile. There was a general consensus among refugees that the diminishing appeal of rape and minority vulnerability had paved the way for this new priority. ('Emergency' and 'urgent' cases were seldom handled swiftly, and agency officials routinely told my informants that the widespread insecurity in the camp area had prevented them from expediting their cases.) Now, it was long-term camp presence that came to have more resettlement potential. Refugee status came to be seen as a process of becoming, as 'old' arrivals increasingly deployed 'long-term suffering' as a justification for being prioritized for resettlement (cf. Malkki 1995). I had been alerted to this trend in an earlier conversation with a close informant who had been worried about the safety of her parents and two brothers back in Somalia following heavy fighting where they lived. When I asked her to advise them to come into exile, however, she laughed off the idea and retorted: 'It is late hours now. Even if they come, they will not get resettlement since old refugees are the ones going abroad.' Her views largely lend credence to Horst's (2006) claim that, despite the radical circumstances of war, Somali refugee flight has often also entailed a form of choice based on the availability of support in acquiring resources at the destination. For this particular informant and a few others I talked to, resettlement was an important consideration in informing one's choice of going into exile. Because of the ever-moving categories of vulnerability, however, many refugees understood that, in the future, they might be forced to abandon vulnerabilities they had meticulously cultivated if priorities in resettlement schemes moved to a new focus.

\section{Becoming a refugee}

The feeling that those with long-term camp experience had a right to be resettled was largely entrenched by the launch of a large-scale resettlement programme in 2006 that specifically targeted those who had stayed longest (and who were deemed to be the most unlikely to return home). The pitching of resettlement claims based on long-term camp stay by people such as Moha was, therefore, an expression of the way in which the accumulation of camp experience nurtured and sustained resettlement aspirations. Basically, 'old' refugees perceived their status as a form of capital that corresponded to 'normal' vulnerability in the post-2006 era. New/old categories had become important structuring principles that also captured clan realities in the context of the way in which kinship had initially shaped flight patterns. 
The linking of long-standing camp experience to resettlement eligibility has temporal and practical implications for the ways in which camps are conventionally understood. Refugee camps are often perceived as temporary settlements with few prospects (see, for example, Harrell-Bond 1986). However, the uncertainty generated by temporal humanitarian imaginings has now become a basis for deploying long-term camp stay as a form of vulnerability. The UNHCR might understandably have regarded refugees with local IDs and those with close Kenyan relatives as fraudulent cases if they perceived that such people had the potential to integrate locally. The organization might similarly have perceived that supplying refugee households with firewood (CASA Consulting 2001) and resettling about 12,000 Somali Bantu minorities (Besteman 2013) was sufficient to have resolved the then pressing vulnerabilities. However, its criterion of privileging long-term camp presence while excluding those with ties outside Dadaab had infused the camps with a particular appeal, turning them into repositories of privileged 'normal' vulnerability. As a consequence, even those who could afford life outside the camps, such as Moha, tried to maintain a presence there. Those staying outside the camps also kept their vulnerability alive by regularly travelling back whenever the UNHCR conducted refugee verification exercises (Herz 2008).

For many people, being a refugee did not automatically confer one with the right to be resettled, and they considered that 'new' arrivals had not suffered as much as 'older' refugees. This resonates with Malkki's (1995: 114) context in which refugeeness was not simply 'an automatic result of crossing of a national border', for, if suffering was the platform for making resettlement claims, then those who had suffered the longest had more resettlement rights than latecomers. One woman eloquently affirmed this position during an informal discussion:

There are two types of refugees: those who came in 1991 and 1992 and the ones who came recently. Some old refugees went for resettlement and left us behind. UNHCR needs to consider us because we have suffered for twenty years and our children also need a good life. Those who came recently have not suffered like us. They should stay here for some time like we have done before being considered.

As implied by the above views, the moral imperative of amassing experience in suffering that would necessarily imbue one with resettlement eligibility seems to have equipped 'old' refugees with the belief that they were entitled to be considered for resettlement by virtue of having stayed the longest in exile. Certainly, the idea of perceiving resettlement as a 'right' often cropped up when I asked my informants about their future prospects. 'Somalis cannot agree on peaceful coexistence-and I know that because I am one of them. Old refugees should, therefore, be allowed to enjoy their refugee right of going abroad,' Moha repeatedly stated. 'Even if peace returns, I would still prefer to get my resettlement right as an old refugee and maybe return to Somalia when I am totally sure that the peace is permanent,' a woman told me on another occasion. Clearly, a successful return to Somalia, if conditions improve, is more feasible if refugees are resettled in Western countries with good economic prospects than it is if they remain in the camps (cf. Horst 2006). Going by the above sentiments, however, it is also likely that, in the context of unrelenting exile, some people had increasingly invested in preserving their accumulated, prized refugee status. 
The understanding that unbroken long-term camp presence with little outside contact could potentially boost one's resettlement chances was what constantly rendered inconspicuous the wide connections of Somalis. Consider the case of twenty-eight-year-old Amey, who reported having been separated from his parents in 1991 and whose reunion with his mother was revealed in a campbased newsletter only after his resettlement process had been finalized:

The dream that Amey waited for two decades finally became true when the UNHCR contacted him about his departure to his new home, Sweden ... However, Amey's final days in the camp were also filled with [a] mixture of happy and sad emotions. His mother who was missing without a trace for 15 years reunited with him only days before this departure. Amey said he couldn't include his mother because she is not a registered refugee, and was not part of the process. ${ }^{10}$

While it is possible that this reunification might have happened at the stated time, it is not inconceivable that Amey had hidden such information in earlier stages of the resettlement process out of fear that he might be excluded.

The supposedly beneficial implications of long-term camp presence are contrary to the emergency imaginary of humanitarianism (Redfield and Bornstein 2010; Gabiam 2012; Fassin and Vasquez 2005) and differ radically from other refugee situations. Liisa Malkki (1995), for instance, has shown how historical and political consciousness became a major impetus in sustaining the desire of Hutu refugees in Tanzania to return home. A similar desire was overwhelming for Palestinian refugees, who viewed a return to their Palestinian homes as a right (Gabiam 2012). In contrast, the uncertainties surrounding the utilization of local integration or voluntary repatriation as durable solutions have shaped Somalis' collective imagination about seeing resettlement as the preferred solution to their long-term exile. Thus, for instance, there was never a sense among my informants that exile was a place in which to repose in solitude while one waited to go back home. Rather, people sought to overcome the harsh exile situation by pooling the proceeds from diaspora remittances to begin business enterprises while striving to be resettled. As the DC's remarks show, the resilience that refugees exhibited amid the uncertainties of their situation was essentially a source of anxiety for government officials who feared that it would effectively root them in exile.

\section{Conclusion}

The cases outlined above illustrate the intractable paradoxes institutionalized by humanitarian practices that are not aligned with lived realities. From the UNHCR perspective, there were perhaps logical reasons for constantly revising resettlement eligibility in line with changing conditions. It is difficult to contest the logic of prioritizing rape as a form of vulnerability in the context of traumatic ordeals that victims endure. Bringing minorities to the forefront of the resettlement gaze might also have been justified in light of their exceptional war

\footnotetext{
${ }^{10}$ 'Refugee of the month', The Refugee Newsletter, September 2010.
} 
experiences. And in 2006, when the spotlight in resettlement eligibility turned to those who had stayed longest in the camp, such a policy was doubtless justified in order to allay the political concerns of the time that this group was becoming permanently rooted in exile. However, the ever-moving categories of suffering engendered a pervasive sense of uncertainty in refugee lives, particularly because of the arbitrary nature of humanitarian decisions.

Somali refugees' circumstances are evidently dire due to the difficult context of scarcity and humanitarian practices that institutionalize uncertainty and suspicion in social relations. It is, however, unproductive to view the social world of refugees through the lens of 'bare life', as this would endorse a partial understanding of camp dynamics. Theorizing the concept of uncertainty has shed new light on the social navigation of Somalis who often sought to produce continuity in their lives in difficult circumstances. Humanitarianism in its most recent guise put a premium on long-term, disconnected camp residence. It also encouraged refugees to exhibit some form of helplessness to keep the need for compassion alive. However, Somalis sought to positively transform their lives. This is an illustration that vulnerable people have the capacity to resist unrealistic bureaucratic prescriptions despite the humanitarian aims of perceiving refugeeness as 'bare life'.

The importance of resettlement to the camp's enduring existence is illustrated by the emergence of new/old distinctions as important structuring principles. The understanding that refugeeness was a process of becoming - in relation to the way in which 'normal' cases had increasingly gained an elevated status in resettlement schemes - is what contributed to institutionalizing these categories. This did not, however, imply that all refugees looked forward to accumulating long-term experience as a way of securing their futures. Perceiving long-term camp residence as a desirable form of vulnerability was, indeed, a fragile discourse that could possibly pave the way for a different metric of assessing vulnerability. Those who perceived that it was 'late hours' to be advising their relatives in Somalia to come into exile were evidently expressing their uncertainty about what might next be prioritized in resettlement schemes if 'normal' vulnerability lost its value.

Resettlement is coveted in many African refugee contexts due to the unproductiveness of camps as spaces for hosting refugees and the generalized poverty in many of these settings (see, for example, Thomson 2012; Sandvik 2011). What is unique in the Somali context is the way in which people apprehend long-term camp stay as a form of vulnerability that sustains resettlement aspirations. Relatedly, the Somali fluidity and practice of scattering family members demonstrate that international principles (such as family unity) are not always universal. There is, therefore, a need for humanitarianism to abandon its categorization of people as 'refugees' and 'locals' and to pay attention to local nuances and complexities. The realities on the ground may question the logic of drawing an indelible line between the lives of such people.

\section{Acknowledgements}

I am indebted to Henrietta Moore and Harri Englund for their insightful comments. An earlier version of the article was presented at the Bayreuth Academy of Advanced 
African Studies under the theme 'Future Africa - Visions in Time'. I am grateful to Erdmute Alber, Lena Kroeker and the other participants at the conference for their helpful suggestions. I am also grateful to the anonymous reviewers of Africa, and to Matei Candea, Cindy Horst and Ross Porter for their invaluable comments. The Commonwealth Scholarship Commission in the UK provided funding for the fieldwork on which this article is based. My deepest appreciation goes to the people of Dagahaley for their hospitality.

\section{References}

Abdi, C. M. (2015) Elusive Jannah: the Somali diaspora and a borderless Muslim identity. Minneapolis MN: University of Minnesota Press.

Besteman, C. (1999) Unravelling Somalia: race, violence, and the legacy of slavery. Philadelphia PA: University of Pennsylvania Press.

Besteman, C. (2013) 'Somali Bantus in a state of refuge', Bildhaan: An International Journal of Somali Studies 12: 11-33.

Boholm, Å. (2003) 'The cultural nature of risk: can there be an anthropology of uncertainty?', Ethnos 68 (2): 159-78.

Branch, A. (2009) 'Humanitarianism, violence, and the camp in northern Uganda', Civil Wars 11 (4): 477-501.

Calkins, S. (2016) Who Knows Tomorrow? Uncertainty in north-eastern Sudan. New York NY: Berghahn Books.

CASA Consulting (2001) Evaluation of the Dadaab Firewood Project. Geneva: Evaluation and Policy Analysis Unit, United Nations High Commissioner for Refugees (UNHCR).

Crisp, J. (2005) 'No solutions in sight: the problem of protracted refugee situations in Africa' in I. Ohta and Y. D. Gebre (eds), Displacement Risks in Africa. Kyoto: Kyoto University Press.

Fassin, D. and P. Vasquez (2005) 'Humanitarian exception as the rule: the political theology of the 1999 Tragedia in Venezuela', American Ethnologist 32 (3): 389 405.

Gabiam, N. (2012) 'When "humanitarianism" becomes "development": the politics of international aid in Syria's Palestinian refugee camps', American Anthropologist 114 (1): 95-107.

Goldsmith, P. (1997) 'The Somali impact on Kenya, 1990-1993: the view from outside the camps' in H. M. Adam and R. Ford (eds), Mending Rips in the Sky: options for Somali communities in the 21st century. Lawrenceville NJ: Red Sea Press.

Haram, L. (2004) 'Visiting the issue of uncertainty in contemporary African lives: an introduction', African Sociological Review 8 (1): 1-10.

Harrell-Bond, B. (1986) Imposing Aid: emergency assistance to refugees. New York NY: Oxford University Press.

Harrell-Bond, B. (2002) 'Can humanitarian work with refugees be human?', Human Rights Quarterly 24 (1): 51-85.

Herz, M. (2008) 'Somali refugees in Eastleigh, Nairobi' in H. Wright (ed.), Instant Cities. London: Black Dog Publishing.

Horst, C. (2006) Transnational Nomads: how Somalis cope with refugee life in the Dadaab camps of Kenya. Oxford: Berghahn Books. 
Hyndman, J. (1996) 'Geographies of displacement: gender, culture and power in UNHCR refugee camps, Kenya'. PhD thesis, University of British Columbia.

Ikanda, N. F. (2014) 'Kinship, hospitality and humanitarianism: "locals" and "refugees" in northeastern Kenya'. PhD thesis, University of Cambridge.

Jansen, J. B. (2008) 'Between vulnerability and assertiveness: negotiating resettlement in Kakuma refugee camp, Kenya', African Affairs 107 (429): 569-87.

Jenkins, R., H. Jessen and V. Steffen (2005) 'Matters of life and death: the control of uncertainty and the uncertainty of control' in R. Jenkins, H. Jessen and V. Steffen (eds), Managing Uncertainty: ethnographic studies of illness, risk and the struggle for control. Copenhagen: Museum Tusculanum Press.

Lewis, M. I. (1998) 'Doing violence to ethnography: a response to Catherine Besteman's "Representing violence and 'othering' Somalia", Cultural Anthropology 13 (1): 100-8.

Lewis, M. I. (1999 [1961]) A Pastoral Democracy: a study of pastoralism and politics among the northern Somali of the Horn of Africa. New Brunswick NJ: Transaction Publishers.

Lindley, A. (2008) 'Protracted displacement and remittances: the view from Eastleigh, Nairobi', New Issues in Refugee Research 143: 1-18.

Lochery, E. (2012) 'Rendering difference visible: the Kenyan state and its Somali citizens', African Affairs 111 (445): 615-39.

Lyons, T. (1994) 'Crises on multiple levels: Somalia and the Horn of Africa' in A. I. Samatar (ed.), The Somali Challenge: from catastrophe to renewal? Boulder CO: Lynne Rienner.

Malkki, L. (1995) Purity and Exile: violence, memory, and national cosmology among Hutu refugees in Tanzania. Chicago IL: Chicago University Press.

Markakis, J. (1987) National and Class Conflict in the Horn of Africa. Cambridge: Cambridge University Press.

Pandolfi, M. (2008) 'Laboratory of intervention: the humanitarian governance of the postcommunist Balkan territories' in M. D. Good, S. T. Hyde, S. Pinto and B. J. Good (eds), Postcolonial Disorders. Berkeley CA: University of California Press.

Redfield, P. and E. Bornstein (2010) 'An introduction to the anthropology of humanitarianism' in E. Bornstein and P. Redfield (eds), Forces of Compassion: humanitarianism between ethics and politics. Santa Fe NM: School for Advanced Research.

Sandvik, B. K. (2011) 'Blurring boundaries: refugee resettlement in Kampala between the formal, the informal, and the illegal', PoLAR: Political and Legal Anthropology Review 34 (1): 11-32.

Thomson, J. M. (2012) 'Black boxes of bureaucracy: transparency and opacity in the resettlement process of Congolese refugees', PoLAR: Political and Legal Anthropology Review 35 (2): 186-205.

Ticktin, M. (2006) 'Where ethics and politics meet: the violence of humanitarianism in France', American Ethnologist 33 (1): 33-49.

UNHCR (2011) UNHCR Resettlement Handbook. Geneva: United Nations High Commissioner for Refugees (UNHCR).

UNHCR (2015) UNHCR Refugee Resettlement Trends 2015. Geneva: United Nations High Commissioner for Refugees (UNHCR). 
Utas, M. (2005) 'Victimcy, girlfriending, soldiering: tactic agency in a young woman's social navigation of the Liberian war zone', Anthropological Quarterly 78 (2): 403-30.

Vigh, H. (2009) 'Motion squared: a second look at the concept of social navigation', Anthropological Theory 9 (4): 419-38.

\begin{abstract}
Refugees are generally viewed as a transitory problem. In many African countries, however, protracted refugee situations have turned the temporary refugee state into a more or less permanent phenomenon. In this article, I draw on the concept of uncertainty, and on claims that suspicion structures humanitarianism, to examine how long-term residents in Dagahaley refugee camp in Kenya attempted to make themselves worthy of being considered for resettlement. I demonstrate how the incompatibility between the UNHCR's resettlement criteria and Somali refugees' lived realities provided both sets of actors with a resource: they used understandings of vulnerability as a means for making or denying resettlement claims. Refugeeness is a process of becoming, premised on how earlier arrivals deployed long-term suffering as a justification for being prioritized for resettlement. These dynamics resulted in the emergence of 'new' and 'old' refugee distinctions through which the meanings of vulnerability were redefined.
\end{abstract}

\title{
Résumé
}

On considère généralement les réfugiés comme un problème transitoire. Dans beaucoup de pays africains, cependant, les situations de réfugiés prolongées ont transformé l'état de réfugié temporaire en phénomène plus ou moins permanent. Dans cet article, l'auteur s'appuie sur le concept d'incertitude, et sur l'assertion selon laquelle la suspicion structure l'humanitarisme, pour examiner comment des résidents de longue durée du camp de réfugiés de Dagahaley au Kenya ont tenté de se faire valoir comme candidats à une réinstallation. Il démontre comment l'incompatibilité entre les critères de réinstallation du HCR et les réalités vécues des réfugiés somaliens a doté ces deux catégories d'acteurs d'une ressource : ils ont utilisé des interprétations de la vulnérabilité comme moyen de revendiquer un droit à la réinstallation ou de le refuser. La qualité de réfugié est un processus de devenir basé sur la manière dont les arrivants précédents ont utilisé la souffrance de longue durée comme justification à être prioritaires en matière de réinstallation. Ces dynamiques ont abouti à l'émergence d'une distinction entre « nouveaux » et « anciens » réfugiés à travers laquelle la signification de la vulnérabilité a été redéfinie. 